\title{
HUMAN GENETIC ENGINEERING IN THE SOUTH AFRICAN CONTEXT WITH ITS INEQUALITIES: \\ A DISCOURSE ON HUMAN RIGHTS AND HUMAN DIGNITY ${ }^{1}$
}

\author{
Manitza Kotzé \\ Systematic Theology and Ecclesiology \\ Stellenbosch University
}

\begin{abstract}
There are still severe inequalities in presentday democratic South Africa; this is no secret. The ever-widening gap between the rich and the poor also contributes to increasing disparities of access to health care and medical treatment, as well as the ability to afford them. Human genetic engineering (HGE) is fast becoming an everyday reality and, though it is not forecast to become commercially available in South Africa very soon and many of the promised benefits are still very far in the future, anticipatory reflection is needed. This article considers just one of the challenges that HGE poses to Christian ethics within the South African context and its inequalities, especially with regards to health care, as part of the discourse of human dignity and human rights.
\end{abstract}

Key Words: Human Rights; Human Dignity; Genetic Engineering; Social Justice

\section{Introduction}

With the development and continued developing of medical technology, treatments become available without the time to reflect ethically on them. Human genetic engineering (HGE) is fast becoming an everyday reality and poses a myriad of ethical questions, especially to the field of theological ethics, for it deals closely with theological concepts such as creation; particular perspectives on God as Creator; perspectives on human beings as created beings; human beings created in the image of God; human dignity; and human creativity. Even in secular discourse, the phrase often used in ethical discussion on HGE is 'playing God"'.

This article examines the ethical issues that the impending availability of $\mathrm{HGE}^{3}$ pose in presentday South Africa and its inequalities, especially with regards to health care as a human right as part of the discourse on human dignity. In the first section of this paper, the health care inequalities that exist in presentday South Africa will be outlined briefly. In the second section, the question whether health care could be viewed as a human right will be

This article was first presented as a paper at the Theological Society of South Africa "Land, Liturgy and Life" Conference held 19-21 June 2013 at the University of the Western Cape.

2 For further discussion on this phrase and its implications, see, for example, Jonathan Glover (2006:63); Thomas Shannon (2000:75-76); Audrey Chapman (1999:52-57) and Ted Peters (1998:8-13).

Although the ethical implications and issues raised by the genetic engineering of human beings are numerous and diverse, this article will be focusing only on one aspect, namely the matter of access and social justice within the South African context with its inequalities. 
discussed and in the third section, health care within the context of HGE will be brought into conversation with the human dignity discourse.

\section{Health Care Inequalities in the South African Context}

It is known widely that even in presentday, democratic South Africa there are still severe inequalities. The ever-widening gap between the rich and the poor also contributes to increasing disparities with regard to service delivery and access to health care and medical treatment, as well as the ability to afford it.

Section 21(1)(a) of the South African Constitution states that everyone has the right of access to health care within available resources, whilst Section 28(1)(c) grants all children the right to basic health care services. The International Bill of Rights recognises justice and fairness, and provides that the law should prohibit any discrimination on any grounds. Although these rights are guaranteed, it is also clear that this does not mirror the reality.

It is common knowledge that under the apartheid government racial discrimination affected the health of Black, Coloured and Indian people and that the inheritance and legacy of this discrimination contributes to continued discrepancy between the services that South Africans of different races are able to access, which includes health care services. Adila in Health and Democracy: A guide to human rights, health law and policy in post-apartheid South Africa, attributes this discrimination also to social conditions that resulted in ill health, the segregation of health facilities, unequal spending on health services and the failure of professional medical bodies and civil society to challenge the way that health care was managed under apartheid. The first truly democratic government in South Africa, elected in 1994, inherited various disparities at the level of health care, such as racial, geographic and public versus private inequalities (2007:11-16). As Sampie Terreblanche states further in A History of Inequality in South Africa: 1652-2002, since 1994, "a continuation of unequal power relations, unfree labour patterns, and uneven socioeconomic development" is seen (2002:20). He elaborates:

The democratic government that assumed power in 1994 inherited a rather contradictory legacy. On the one hand, it inherited the most developed economy in Africa, with a modern physical and institutional infrastructure. On the other, it inherited major socioeconomic problems, including high levels of unemployment; the abject poverty of 50 percent of the population; sharp inequalities in the distribution of income, property, and opportunities; and high levels of crime and violence. What makes these problems much more pressing is the fact that it is mainly black South Africans - and particularly Africans - who are at their receiving end (Terreblanche 2002:4).

In 2002, the South African government claimed that between 1994 and 2002, 9 million people, who had not had access previously, had been given access to clean water, and 1.5 million households to electricity. Telephone connections had been provided to 1.3 million households, 1 million houses had been built for those who had previously had no formal shelter, free medical services had been provided to expectant mothers and children younger than seven, food programmes had reached 5 million children and rural communities had benefitted from infrastructural development (Terreblanche 2002:28). This seems to be an encouraging picture, proving that the inequalities of the past are rapidly being eradicated and that in just eight short years, the democratic South African government has bridged the gap of inequality and taken, not just small steps, but giant leaps down the road to equality for all. Terreblanche, however, then dashes this idealistic representation by going on to declare: 
Many of the electricity, water, and telephone connections are cut off every month because users cannot afford to pay for them. Many of the houses built are of poor quality. In 1999 the department of water affairs admitted that many of its water provision projects had fallen into dysfunction or disrepair. The removal of farmers' subsidies as well as labour reforms and droughts in the agricultural sector have led to a decline in employment of blacks in this sector from 1,4 million to only 800000 . The improvement of health services in rural areas has led to a dramatic drop in the quantity and quality of health services in urban areas... (Terreblanche 2002:28).

Francis Wilson, in Historical Roots of Inequality in South Africa, further indicates that the majority of income goes to the top $10 \%$ of the South African population and she uses data from Leibbrandt, Woollard, Finn and Argent's 2010 study to prove that the richest 10\%, who earn more than R400 000 per annum per household, earns more than the other $90 \%$ combined. In terms of poverty, the bottom 30\% of South African households all earn well under R20 000 per annum. Around 70\% of the country's population earn only $17 \%$ of the total income. Adding to these figures are the 'astronomical levels of unemployment', where depending on the definition, between $25 \%$ (when defined narrowly) and $41 \%$ (when defined inclusively) of South Africans who want to work are unemployed. As Wilson contends: "Despite its best intentions, despite every effort to develop the most effective policy and despite the firm expectations of its voters, the democratic government of the new South Africa has been able to do little to shift the levels of poverty, of unemployment and of inequality which it inherited from the apartheid regime in 1994" (2011:2-3).

It is, however, not the intention of this paper to examine the causes and historical development of the inequalities that exist at present in South African society, but rather to examine how the current conditions would or would not contribute to the ethical discussion surrounding HGE.

\section{The Human Right to Health in the Discussion of Human Genetic Engineering}

In this article I will argue that human beings have an inherent human right to health, rather than to health care. This statement does not exclude health care from the dimension of health, but rather aims to work with a more encompassing and comprehensive parameter than simply the right of access to health care services.

This does not mean, however, that health care should not be included in the right to health, or that governments have any less of a duty to look after the health of its people. On the contrary, by viewing the right to health as much more than simply access to health care services, I argue that a much more holistic view of human health care is at work - one that also calls attention to the other features that contribute to health, such as sanitation, housing, diet, and so forth, and appeals to the responsibility of government to look after these basic human needs of those who cannot afford to do so themselves. Therefore, the notion of access to health care is included, but more than that, access to a life of health and dignity in this comprehensive sense is what is emphasised.

To investigate access to health care services further and give an appraisal of how accessible HGE could be to people living in South Africa, taking all of the inequalities previously mentioned into account, it is important also to distinguish between health and health care and between the right to health as an element of basic human rights and forming part of the discussion on human dignity, and the right to health care. I contend that simply arguing, whether as part of the human dignity discourse or not, that people have a 
human right to health care ${ }^{4}$ fails to take many of the complexities that accompany health into account. Health ${ }^{5}$ is a concept that has much more far-reaching associations and underlying causes than simply access to a clinic. People with free and unrestricted access to the best physicians in the world will not be in good physical shape if they are unable to purchase fresh and healthy food. Being treated by several world-acclaimed specialists will not make someone get well when they do not have access to clean drinking water and hygienic bathroom facilities at home. Being healthy, and having the human right to health, then, is about much more than access to health care and medical services.

In Medicine and Public Health, Ethics and Human Rights, a report for the Hastings Centre, Jonathan Mann also points out that the contribution of medicine to health is, in fact, limited, citing that only a sixth of gained life expectancy is attributed to medicine and that only $10 \%$ of preventable premature deaths are associated with a lack of health care (1997:7). This same sentiment is echoed by many other researchers, for example Dan Brock, who states in Broadening the Bioethics Agenda: "But health care's impact on both health and health inequalities is quite limited; for example, medical care is estimated to account for only about one fifth of life expectancy gains in the twentieth century" (Brock 2000:31).

It would seem then, that it is rather socio-economic issues than health care access that are at stake here, although access to health care undeniably also has a role to play.

\section{A Right to Health Care?}

"To say that there is a right to health care does not imply a right to equal access, a right that whatever is available to any shall be available to all" (Fried 1976:29). Regarding the 'right' to health care access, in the Hastings Centre Report 6 Vol. 1, Equality and Rights in Medical Care, Charles Fried also gives an informal definition of what a 'right' is, stating that it is more than just what is in an individual's interest or the preferable state of affairs or state of being. A right is what someone is entitled to, not just what they would like or prefer to have, but what must be had and may be demanded when lacked. This statement, however, is problematized when he goes on to state that the right to equality could mean that even if someone is not necessarily entitled to something, equality could be interpreted to mean that that person should still be able to receive the same as someone else (1976:30).

This could also mean that the development of new treatments and medicines, which would most likely be expensive, may be terminated because of the argument "if we provide it to any we must provide it to all, therefore perhaps we should provide it to none" (Fried 1976:31). John Harris also states that "fairness does not require that I should not try to protect myself because others cannot; it does not require that benefits should not be provided to any until they can be made available to all" (2007:28).

\footnotetext{
4 In this article, the term "health care" is used as an adjective to refer to that which relates to health care, and as a noun to indicate "the prevention, treatment, and management of illness and the preservation of mental and physical well-being through the services offered by the medical and allied health professions" (http://medicaldictionary.thefreedictionary.com/health+care accessed on 19 July 2013).

5 The term "health" used in this article follows the definition of the World Health Organization, namely the "state of complete physical, mental and social well-being and not merely the absence of disease or infirmity" (http://www.who.int/about/definition/en/print.html accessed on 19 July 2013). This is very important for the manner in which I view health in this article, ; as encompassing more than simply the absence of disease and including socio-economic and social aspects.
} 
Additionally, it has also been argued that the only right that can be guaranteed by any government is a freedom of action and that health care, as opposed to this, is a service offered and not a right. Rather, it could be stated that people have the right to health, which would imply that they have the right to be protected from risks or hazards to health that would be the actions of others, but not that the government should be under any obligation to provide health goods and services. On the other hand, others, such as Tom Beauchamp, contend that virtually all major diseases are caused socially, rather than individually. From this perspective, the only diseases against which people have a right to be protected are those that are brought about by entirely natural causes (Beauchamp \& Faden 1979:123-125).

In any discussion on the right to health care, the distinction should be made between negative and positive rights. A negative right would be the freedom to pursue a course of action or to enjoy conditions and a positive right the entitlement to acquire goods, opportunity or service. Whilst it would seem that the right to health care is purely a positive right, if health care is broadened to include certain abstentions from actions that are intended as precautionary and protective measures, aspects of negative rights are also present (Beauchamp \& Faden 1979:120-121).

This concept of restricting human rights becomes clear when we consider the so-called positive rights, which infringe upon the rights of other human beings. If health care is viewed as such a right, it would be unacceptable if some people were unable to obtain it and the government would be compelled to ensure that every person has access to health care, even those who are not financially able to buy it on their own. Given that the government's only means of paying for this service would be taxation, and this taxation, as Bradley explains in Positive rights, negative rights and health care, would then provide unearned goods to one group and, as Peikoff argues further, would be "an immoral infringement of the right of the taxed to keep the fruits of their labour". He goes on to state that a system in which someone has a "right to anything at others' expense means that they become rightless". Barlow also maintains that something cannot be called a right if its provision places an 'intolerable burden' on others (Bradley 2010:838).

By the argument that health care is not a right, it is not claimed that it is good, or even fair, for people to be without access to health care. Based upon the previous argument, those who cannot afford health care by themselves are forced to rely on voluntary charity. The contention is, however, that it is also not good, or fair, to provide the poor with health care when it is at the expense of other people's rights (Bradley 2010:839). Bradley, however, then goes on to state that protecting even the negative rights of life, liberty, and the pursuit of happiness might require some positive action on the part of citizens possibly through the paying of taxes or submitting themselves to the draft. As Shue puts it, "a demand for physical security is not normally a demand simply to be left alone, but a demand to be protected against harm". When referring to the positive rights to life, liberty, and the pursuit of happiness, it is expected that the government will do something to protect those rights. In his opinion, the clear moral boundary that Peikoff draws around negative rights thus disappears, as does his basis for claiming that health care cannot be a right (Bradley 2010:839).

On the other hand, there are many possible objections to this argument, such as redistribution and equality of need. In line with Peikoff's argument, it could be argued that whilst everybody's healthcare needs vary, nobody has a greater need than anybody else for life, liberty, and the pursuit of happiness, leading to the conclusion that, conceivably, this equality of need could exclude health care from the domain of true human rights. 
Anton van Niekerk also voices the conviction that "care about people's physical and mental health is neither a consumable and therefore marketable commodity" (1993:2). Rather, he views health care to be both a moral command and a responsibility (1993:2).

Bradley's counter-argument, however, states that in reality, even the preservation and continuance of a police force involves a redistribution of wealth; whereas effective law enforcement might be an advantage to all - those individuals with no income cannot contribute to the tax needed to maintain law enforcement, and as a result, compared with their contribution to the tax pool, these individuals are receiving a greater service than taxpayers, for not only did they not contribute anything, but seeing as they might well be homeless or living in more dangerous areas, they most likely benefit quite a bit more from the presence of a good police force than the average, taxpaying citizen. Wealthier individuals, who have the option of hiring additional, private security, also reduce the value that they obtain from law enforcement, but still pay the full tax. Consequently, from the point of view of both the wealthy and the poor, the maintenance of negative rights can be redistributive; thus, redistribution cannot serve as the moral distinction between positive and negative rights (2011:839).

In a rights-based approach to public health, as Elvira Beracochea, Dabney Evans and Corey Weinstein make clear in the introduction to Rights-Based Approaches to Public Health, everyone has the right to access current medical knowledge regarding prevention and treatment and everyone has an equal right to resources to ensure that the same burden of disease our generation inherited is not passed on to the next (2011:4). A rights-based approach also conflicts with a needs-based approach, where the health problems of a group or community is prioritised in order to overcome them in a classic example of utilitarianism, but one that is at odds with a key principle of human rights; that rights are universal. Pertaining to health care, a rights-based approach would argue that everyone has the right to health and that no one has more of a right than another (Beracochea, Evans \& Weinstein 2011:11).

Jason Eberl, Eleanor Kinney and Matthew Williams, however, state that the problem with the idea of health care as a commodity distributed pursuant to market forces is that, for the great majority of people, "many health care services are simply not affordable; and while the health insurance market should render access to health care services more affordable, the cost of private health insurance remains economically unfeasible for many" (2011:551). Whilst the more liberal side of the debate would propose that the government should play more of a role in financing and the provision of health care services to ensure equal access, the question remains whether there is a middle ground between the notions of health care as a right and as a market commodity. The major factor in mitigating a middle ground is the obvious need for public subsidies, defrayed by taxpayers, to make increasingly costly health care services available to most, if not all, its members. It is also noteworthy that there is no developed country in the world in which health care services are financed solely by the private funds of patients. Since World War II, most developed countries have enacted public programmes of some variation to defray the costs of health care for its citizens (Eberl, Kinney \& Williams 2011:552).

The report of the US President's Commission for the Study of Ethical Problems in Medicine and Biomedical and Behavioral Research (1983), offers such a middle ground, which provides sound guidance in addressing health care in trade policy. The report concluded that health care was neither a right nor a pure commodity, but something in between. The Commission framed its analysis of access to health care "in terms of the 
special nature of health care and of society's moral obligation to achieve equity, without taking a position on whether the term 'obligation' should be read as entailing a moral right," and defined "equitable access to health care" as requiring that "all citizens be able to secure an adequate level of care without excessive burdens"; and it concluded that "society has an ethical obligation to ensure equitable access to health care for all" because of the "special importance of health care" (Eberl, Kinney \& Williams 2011:552-553). In addition, the Commission determined that the societal obligation is balanced by individual obligations and described the content of an individual's obligations:

Individuals ought to pay a fair share of their health care cost and take reasonable steps to provide for such care when they can do so without excessive burdens. Nevertheless, the origins of health needs are too complex, and their manifestations too acute and severe, to permit care to be regularly denied on the grounds that individuals are solely responsible for their own health (Eberl, Kinney \& Williams 2011:553).

If the right to health care is viewed as a right to equality of opportunity, denying any person health care would be to restrict the range of opportunities that would otherwise be open to that individual. Other issues, such as the distribution of wealth and income, however, also greatly influence the equality of opportunity to which a person would have access (Daniels 2001:319).

Norman Daniels comes to the conclusion that a right to health care is important, but that it can, and should, be restricted and that not every medical need gives rise to an entitlement to services. He states that we cannot make the direct conclusion that because an individual has a right to health care, it automatically means that he or she should be entitled to some precise health-care service, even if it is a health-care need (2001:320-321). Onora O'Neill, as Kristen Hessler indicates, further emphasises that a right to universal health cannot be provided. The reasons he gives for this statement is that, in the first instance, universal health cannot be achieved, as total dedication to others' health or even always prioritising health improvements over other action is unachievable. In the second instance, since health is not a commodity that can be distributed, universal health is unachievable (2008:40).

A notion that does not feature in many of these debates is the concept of human dignity. This concept can also serve as a basis for the human right to health in view of biotechnological advances like HE, especially in Christian bioethical dicourse.

\section{Human Dignity}

The conviction that all human beings have inherent value and dignity, simply on the basis that they are human, is more often than not grounded in the confession that they are created imago Dei, in the image of God, in Christian thought.

"Wherever there came to be a concept of 'the human being', the right of human beings as such were formulated too". This means that human rights are not explicitly Christian or European, although it was formulated as such during the time of the Western Enlightenment and made its way into constitutions in that form (Moltmann 1999:117). Jürgen Moltmann sees the need for human rights to expand in two directions: firstly, in the formulation of the fundamental rights of humanity and secondly, by incorporating human rights into the rights of the earth and all other living things (1999:118).

Human dignity is both the root of human rights and the bond unifying different categories of rights, be they protective rights, the rights to freedom, social rights or rights of participation (Moltmann 1999:119). Moltmann clarifies that human dignity is not the elevation of human beings above other living things and cannot be upheld at the expense of 
nature (1999:120). Individual and social rights also belong together and one cannot take precedence over the other (Moltmann 1999:123-124). Moltmann explains it in the following way:

The fact that all human beings are made in the image of God is the foundation of human dignity. Human beings are intended to live in this relation to God. That gives their existence its inalienable, transcendent depth dimension. In their relationship to the transcendent God, human beings become persons whose dignity must not be infringed (Moltmann 1999:122).

For the Christian ethical discussion on HGE, this would mean that human dignity, as humanity created imago Dei must be respected, and that this dignity should not infringe on the created dignity of nature and other living things. Respecting human dignity could be interpreted in some circles as respecting the human genome as it exists in nature and that any interference would be a violation of the human dignity of the individual involved.

I disagree with this type of discourse, however, and instead deem it a breach of the human dignity of the affected individual when the technology exists that is able to repair genetic defects or heal a crippling hereditary disease. Respecting the human dignity of that individual, which includes the right to a life of dignity may very well rather mean offering him or her every chance at a life of dignity, even when that should be materialised through biotechnological intervention. In this instance, a distinction must be made between the utilisation of genetic intervention for enhancement and for healing or curing purposes, although the complexity of this distinction ${ }^{6}$ is realised.

The right to lead a life of dignity is also an inherent part of human dignity (Moltmann 1999:127). For this reason, the bigger issue of economic injustice should be addressed. Relating closely to this, Maura Ryan rightly indicates that in many regions access to basic health care, clean water, satisfactory nourishment, maternal and child care and the treatment and prevention of HIV/AIDS, are far more serious crises than the availability of genetic treatments (2012:974-975).

For this reason, I raise the larger issue of socio-economic justice and not simply the issues with which the conversation on social justice confronts HGE directly, such as the inequality that would exist in access and affordability. Given the large discrepancies that exist in the health care sector at present, these concerns can very easily be argued away. In this regard, one can simply state that the social injustices that they refer to are present in any case and that it does not contribute in a unique way to the Christian bioethical discussion on HGE. Arguing in this way, without taking the broader socio-economic context into account, could lead one to making the case that because the inequalities that these forms of biotechnologies could exacerbate exist already, it does not add anything original to the bioethical discourse.

\section{Human Genetic Engineering and South African Inequalities in Health Care}

It has already been established that great divides exist in the South African context, also in terms of health care. This also then raises questions regarding the aspect of social justice when it comes to the utilisation of HE.

Some scholars, such as for example James Peterson (2012:970-971); Michael Sandel (2007:49) and Gerald McKenny (1997:32-37) argue that this is an impossible distinction to make. Others maintain that to a certain extent, these concepts can indeed be distinguished, of which Allen Buchanan (2011) and Nicholas Agar

(2010:17) are noteworthy examples. 
The first argument levelled against the use of HGE in the context of the existing inequalities is the possibility that those who can afford to utilise this biotechnology would be able to prevent certain diseases in their children, leading to the risk of empathy and concern for these diseases disappearing and turning them into 'low-class' diseases. Furthermore, if illness is thought of as something avoidable, it could also mean that social provision and care for the sick might be reduced (Gavaghan 2007:172-175). Maura Ryan indicates that high-demand genetic therapies such as GE "are likely to be both very costly and (as in vitro fertilization and other reproductive technologies) available only to those who are willing and able to pay for them" (2012:977).

In Our Posthuman Future, Francis Fukuyama further states: "If wealthy parents suddenly have open to them the opportunity to increase the intelligence of their children as well as that of all their subsequent descendants, then we have the markings not just of a moral dilemma but of a full-scale class war" (2002:16). This possibility, of course, also raises significant questions for theological ethics, especially with regards to the previous section on human dignity. If all people are born equally with inherent dignity because they are created imago Dei, what implications could this possible genetic divide have?

In addition, HGE can also be viewed in terms of power, especially given the reality that only a small percentage of the population would be able to afford and access this biotechnology; in short, only the powerful. In Theology and Biotechnology, Cynthia DeaneDrummond refers to the power that is wielded by biotechnology in the agricultural sphere as "becoming a means of oppressing Third World economies and [it] seems to drive a wedge between rich and poor nations" (1997:82). As a result, the long term social consequences have to be taken into consideration. This also confirms that the issue under discussion is much wider and more extensive than simply the right to health care and one that also touches on larger discourses of social justice and human dignity - also from a theological perspective.

Colin Gavaghan sums up the issue at hand: the fear is that unequal access to this kind of technology could cause or exacerbate pre-existing divisions (2007:172). This is a fear that, given the reality of inequalities and the ever-growing divide between the rich and poor in South Africa, does not seem to be unfounded.

\section{Conclusion}

It has been indicated that health care plays a lesser part in determining a person's health. In this article I have argued that in the human rights discourse, the human right to health should be emphasised rather than simply the right to health care. This does not mean, however, that health care should not be included in this right, or that a government have any less of a duty to look after the health of its people. On the contrary, it is my opinion that by viewing the right to health as much more than merely the right to have access to health care services, a much more holistic view of human health care is at work, one that also puts emphasis on the numerous other features that contribute to health, for example sanitation, housing, diet, and so forth, and appeals to the responsibility of government to look after these basic human needs of those who cannot afford to do so themselves. In addition, by accentuating the larger issue of social justice and not simply the matter of access and availability that is directly related to HGE, this article also dealt with the much larger issue of socio-economic justice. 
This, of course, also has extensive and far-reaching implications for the larger discussion on HGE and the impact it would have on the current South African context, with its great and growing gap between rich and poor, or, in other words, between those who would be able to afford this technology, and those who would not have access, were HGE to become commercially available. This is not to say that this biotechnology should not be used for curing and treatment purposes, but rather stresses that social justice be underlined and emphasised in all ethical conversation about its applications.

\section{BIBLIOGRAPHY}

Agar, N 2010. Humanity's End: Why We Should Reject Radical Enhancement. Cambridge, Massachusetts: MIT Press.

Beauchamp, TL \& Faden, RR 1979. "The Right to Health and the Right to Health Care", Journal of Medicine and Philosophy, 4:118-131.

Beracochea, E, Evans, DP \& Weinstein, C 2011, "Introduction: Why do rights-based approaches to health matter?" in E Beracochea, C Weinstein \& DP Evans (eds.), Rights-Based Approaches to Public Health. New York: Springer Publishing Company, pp. 3-18.

Bradley, A 2010, "Positive rights, negative rights and health care", Journal of Medical Ethics 36:838-841.

Brock, DW, 2000, "Broadening the Bioethics Agenda", Kennedy Institute of Ethics Journal, 10:21-38.

Buchanan, A 2011. Beyond humanity? The Ethics of Biomedical Enhancement. Oxford: Oxford University Press.

Chapman, AR 1999. Unprecedented Choices: Religious Ethics at the Frontiers of Genetic Science. Minneapolis: Fortress Press.

Daniels, N 2001. "Is there a right to health care and, if so, what does in encompass?" in H Kuhse \& P Singer (eds.), A Companion to Bioethics. Oxford, Blackwell Publishing, pp. 316-325.

Dean-Drummond, C 1997. Theology and Biotechnology: Implications for a New Science. London: Geoffrey Chapman.

Eberl, JT, Kinney, ED \& Williams, MJ 2011. "Foundation to a Natural Right to Health Care", Journal of Medicine and Philosophy, 36:537-557.

Fried, C 1976. "Equality and Rights in Medical Care", Hastings Centre Report, 6:29-34.

Fukuyama, F 2002. Our posthuman future: Consequences of the biotechnology revolution. New York: Farrar, Straus \& Giroux.

Glover, J 2006. Choosing children: Genes, Disability and Design. Oxford: Clarendon Press.

Hassim, A Heywood, M \& Berger, J 2007. Health and Democracy: A guide to human rights, health law and policy in post-apartheid South Africa. Cape Town: SiberInk.

Harris, J 1998. Clones, Genes, and Immortality: Ethics and the Genetic Revolution. New York: Oxford University Press. 
Hessler, K 2008. "Exploring the Philosophical Foundations of the Human Rights Approach to International Public Health Ethics", in M Boylan (ed.), International Public Health Policy and Ethics, International Library of Ethics, Law, and the New Medicine 42, Springer Science and Business Media, pp. 31-43.

Mann, JM 1997. "Medicine and Public Health, Ethics and Human Rights", Hastings Centre Report, 27:6-13.

McKenny, G 1997. To Relieve the Human Condition. SUNY Press: Albany New York.

Moltmann, J 1999. God for a Secular Society: The Public Relevance of Theology. Minneapolis: Fortress Press.

Peters, T 1998. “Genes, Theology, and Social Ethics: Are We Playing God?” in T Peters (ed.), Genetics: Issues of Social Justice. Cleveland: The Pilgrim Press, pp.1-45.

Peterson, JC 2012. "Ethical Standards for Genetic Intervention", in MT Lysaught, JJ Kotva Jr., SE Lammers \& AD Verhey (eds.), On Moral Medicine: Theological Perspectives in Medical Ethics. Grand Rapids, Michigan: William B Eerdmans, pp. 969-973.

Ryan, M 2012. "Justice and Genetics: Whose Holy Grail?" in MT Lysaught, JJ Kotva Jr., SE Lammers \& AD Verhey (eds.), On Moral Medicine: Theological Perspectives in Medical Ethics. Grand Rapids, Michigan: William B Eerdmans, pp. 973-980.

Sandel, MJ 2007. The Case against Perfection: Ethics in the Age of Genetic Engineering. Cambridge, Massachusetts: Harvard University Press.

Shannon, TA 2000. Made in Whose Image? Genetic Engineering and Christian Ethics. New York: Humanity Books.

Terreblanche, SJ 2002. A History of Inequality in South Africa: 1652-2002.

Pietermaritzburg: University of Natal Press.

Van Niekerk, AA 1993. "Introduction: Health care, ethics and human rights", in AA van Niekerk (ed.), Health Care as Human Right. Stellenbosch: Stellenbosch University, pp. 1-14.

Wilson, F 2011. "Historical Roots of Inequality in South Africa", Economic History of Developing Regions 26 (1):1-15.

http://medical-dictionary.thefreedictionary.com/health+care.

http://www.who.int/about/definition/en/print.html 